there have been exceptions. Unfortunately, in the earlier ones the spots were not looked for sufficiently soon, but in those in which a systematic search was made their appearance was never delayed beyond the third day of pyrexia and occasionally they were seen within twenty-four hours of its onset. The interval from their appearance to that of the rash varied between one and three days. Except in Case 1 the temperature was previously normal or subnormal, so that the onset could be accurately dated. In Case 6 there was slight nasal discharge for three days with normal temperature; in all the others pyrexia was the earliest symptom. Case 8 is specially interesting as it presented no symptoms suggestive of measles and was only examined for the spots on account of the relationship to Case 7. In almost all the cases the prodromal catarrh was very slight, a fact which enhanced the value of the spots. In some of them it is not too much to say that a certain diagnosis was impossible, at that date, apart from their presence. I had not at first the courage to put a child into a ward with other cases of measles on the strength of the spots, with only slight (and in itself insufficient) collateral evidence of infection. Latterly, however, I did so, and in no case did the rash fail to develop. Cases of pyrexia in other conditions, such as serum rash, broncho-pneumonia, and the like, were carefully examined, but only once did I find any condition which could not, with care, be differentiated from the spots. The case was one of diphtheria in which there occurred one evening a temperature of $102^{\circ} \mathrm{F}$. with cough. On examination I certainly thought I saw two or three Koplik's spots and had the patient placed in a ward by himself. Next morning, however, there was no trace of the spots nor did they subsequently develop. The cough proved to be the earliest symptom of a severe attack of diphtherial paralysis. It may be said, then, that making allowance for the shortness of the series, it bears out the conclusion of most writers that Koplik's spots are of much value in the early diagnosis of measles. Other symptoms which will usually be present and may even occur before the pyrexia must not be neglected. It is where these other symptoms are slight and inconclusive as in some of the above cases, that the presence of the spots may decide the diagnosis. They are absent in, roughly, 10 per cent. of recorded cases.

Plaistow, $\mathbf{E}$.

\section{A CASE OF RENAL ABNORMALITY.}

By RUPERT BUTTERWORTH, M.B., B.O. CANTAB., HOUSE PHYSICIAN AT THE DERBYSHIRE ROYAL INFIRMARY, DERBY.

By the courtesy of Dr. $\mathrm{E}$. Rice and Mr. R. H. Luce, under whose care the patient was while in the Derbyshire Royal Infirmary, I am enabled to report what I hope may be considered an interesting abnormality.

A man, aged 34 years, was admitted into the infirmary on May 20th, 1904, with a history of hæmatemesis and he was said to have had some fits the precise nature of which conld not be ascertained. There was no bistory of any renal troable. He was obviously very ill and died a few hours after admission. No hæmatemesis occurred nor did he have any fits during that time. He was somewhat comatose and there was some bleeding from his gums. His tongue was not bitten.

At the post-mortem examination it was found that there were miliary tubercles along the meningeal blood-vessels, there being fairly large aggregations in some places. They were chiefly on the vertex and comparatively scarce at the base. There was congestion of the blood-vessels of the left occipital lobe. The lateral ventricles were considerably dilated. The upper lobe of the right lung was shrunken and airless, the bronchi being hard and dilated. There were no cavities or scars. The bronchial glands were calcareous. The stomach was distended with fluid but contained no blood. There was congestion of the veins at the cardiac orifice.

The interest of the case consisted in the fact that there was only a single kidney, firmly fixed, situated in the middle line. The upper end just overlapped the bifurcation of the abdominal aorta and the main portion lay between the two common iliac arteries. It rested on the fourth and fifth lumbar vertebræ and the upper segment of the sacrum. It was approximately of the size of a normal kidney, if anything sligbtly smaller. As I wished to send "it intact to the St. Mary's Hospital Museum, London, I did not separate it from the ureter to weigh it. For the same reason $I$ did not out it and $I$ am indebted to the curator, Dr. J. F. H. Broadbent, for the description of the kidney on section. In shape it was lobulated and broader at the upper end than at the lower. The renal artery came from the right common iliac. On section Dr. Broadbent states that he found a considerable degree of hydronephrosis with chronic thickening of the calices and connective tissue framework with atrophy of kidney tissue of which there was very little remaining. There was a single ureter six inches in length. It rose from the posterior aspect of the kidney low down. Its lumen was very large, averaging three-quarters of an inch. There was a constriction just before it entered the bladder, into which it opened by a single orifice in the middle line. There was no stone found or any reason to believe that the dilatation was other than congenital. The bladder wall was normal. The rectum crossed the single ureter almost at right angles and dipped down into the pelvis on the right side of the bladder-a curious relation, but it did not appear to have exerted pressure on the ureter.

The whole condition is perhaps more interesting from a surgical than from a medical point of view, although it seems extraordinary that the small amount of kidney tissue was sufficient, and should such an abnormality occur in a woman it would be a possible cause of obstructing labour by diminishing the conjugate.

Derby.

\section{AN UNUSUAL CASE OF MUSCULAR ATROPHY.}

By W. LANGDON BROWN, M.A., M.D. Cantab., M.R.C.P LOND,

ASSISTANT PHYSICIAN TO THE METROPOLITAN HOSPITAL; JUNIOH DEMONSTRATOR OF PRACTICAL MEDICINE, ST. BARTHOLOMEW'S HOSPITAT.

THE following case of progressive wasting of the muscles. of the shoulder girdle which I have had under observation for two and a half years presents some unusual and interesting features.

The patient first came under my care in November, 1901. He was then $13 \frac{1}{2}$ years of age. $H e$ was said to have lost power in the left arm at the age of five months. Since that time the left arm had always been smaller than the right but there had been no progress in the wasting till one year ago. One brother had died in an asylum, otherwise there was nothing in the past history or family history bearing on the case. At first sight the diagnosis seemed to lie between old infantile palsy or Erb's juvenile paralysis. The history was untrustworthy, so that it was difficult to estimate how much of the wasting was recent and how much of it was old. But the fact that the left arm, measured from the coracoid process to the styloid process, was an inch shorter than the right showed that some of the wasting must have been of long standing. Yet a response was elicited from all the muscles both to the cell and to the coil currents. This made it look very like a myopathy, but there were two points strongly against this: (1) the affected muscles showed marked fibrillary tremors; and (2) the grouping of the muscles was quite different from that found in the myopathies, as the following table shows:-

$\left.\begin{array}{l}\text { Erb's type. } \\ \text { Biceps } \\ \text { Triceps } \\ \text { Supinator longus } \\ \text { Deltoid } \\ \begin{array}{l}\text { Supraspinatus } \\ \text { Infraspinatus }\end{array}\end{array}\right\}$ natrophied.

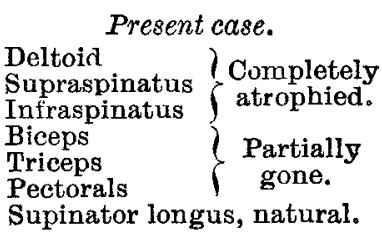

In all other respects the boy appeared normal and in good general health. In 1902 the right side began to get weak also and fibrillary tremors were noticed on this side. In October, 1902, he was admitted to the National Hospital for the Paralysed and Epileptic, Queen-square, under the care of Sir William Gowers; the registrar has kindly informed me that the opinion formed at that time was that the boy had infantile palsy with doubtful muscular atrophy occurring subsequently. I did not see him again till the end of 1903 when I was struck with the increased loss of power in the A A 3 
left arm and the wasting of the left hand. It was stated that he had begun to have fits of unconsciousners during which he struggled and occasionally passed urine, but this was never seen during his stay in the Metropolitan Hospital where he was under my care from Feb. 29th to March 21st, 1904. His condition on admission was as follows. He was a healthy looking lad, 16 years old. His arms were very thin, especially the left. On this side the deltoid was almost absent, the head of the humerus, the acromion, and the coracoid process being very distinctly seen. The supraspinous and infraspinous fossæ did not appear to be occupied by any muscle at all. The trapezius was present but not well developed. There was very little of the pectoralis major remaining. The biceps and triceps were much wasted. In all these muscles fibrillary tremors were to be seen. There was no noticeable wasting of the muscles of the forearm. The thenar eminence of the hand was flattened and the interossei appeared to be slightly wasted. Formerly he could raise the left arm above the head without much difficulty; now he had to adopt the following complicated manceuvre. The upper arm was first approximated to the chest and the scapula fixed. The forearm was then flexed and finally the whole arm was raised by simultaneous extension of the forearm and rotation of the shoulder forward. On the right side the supraspinatus, infraspinatus, and deltoid were all slightly wasted and showed fibrillary tremors. The muscles of the abdomen and legs were not wasted. The knee-jerks were normal, there was no spasticity, the gait was not affected, and no disturbance of sensation could be discovered. The electrical reactions tabulated below were very different from those obtained in 1901 :-

\section{Left Side.-I. Responding neither to Cell Current nor to} Coil Current.

Spinal origin.

Deltoid 4th and 5th C.

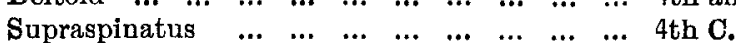

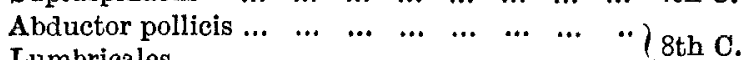

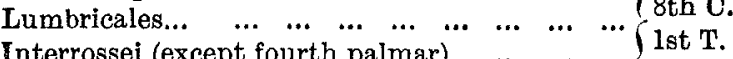

II.-Not Responding to Coil Current, Sluggish to Cell Current.

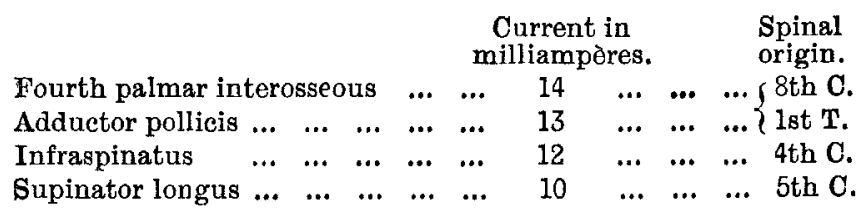

III.-Responding to Coil Current, somewhat Sluggish to Cell Current.

Current in milliamperes.

Spinal origin.

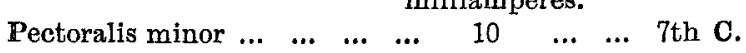

$\begin{array}{lllllllllllll}\text { Biceps } & \ldots & \ldots & \ldots & \ldots & \ldots & \ldots & 8 & \ldots & \ldots & 5 \text { th and } 6 \text { th } \mathbf{C} .\end{array}$

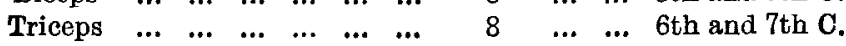

IV.-Reacting readily to both Currents.

Current in Spinal origin.

\begin{tabular}{llllllllll} 
& \multicolumn{1}{c}{ milliamperes. } \\
Pectoralis major &.. & $\ldots$ & $\ldots$ & $\ldots$ & 6 & $\ldots$ & $\ldots$ & 6th and 7 th $\mathbf{C}$. \\
Trapezius & $\ldots$ & $\ldots$ & $\ldots$ & $\ldots$ & $\ldots$ & 6 & $\ldots$ & $\ldots$ & 2nd and 3rd $\mathbf{C .}$
\end{tabular}

Extensors and flexors of forearm $6 \quad \ldots \quad \ldots \quad$ th and 7 th $\mathbf{C}$.

Right side.-All responded to cell current though the infraspinatus required a current of more than 15 milliampères and all responded to coil current.

That the condition is a progressive one there can now be no doubt. The increased loss of power is well shown by the difficulty experienced now in raising the arm, the increased wasting is seen in the intrinsic muscles of the hands, and the increased degeneration is amply attested by a comparison of the electrical reactions in 1901 and 1904. Old infantile palsy cannot account for these facts, especially as fibrillary tremors can now be seen on the right side. Erb's juvenile type of muscular dystrophy is negatived by the distribution of the wasting and by the disappearance of coil current excitability in certain muscles without loss of cell current excitability. Moreover, fibrillary tremors do not occur in myopathies. There remains the spinal type-chronic anterior poliomyelitis. Looking at the spinal representation of the muscles involved we see that the fourth, fifth, and eighth cervical and first thoracic segments are most affected, while intermediate segments, the sixth and seventh cervical, show less degeneration. And the degeneration in the lowest segments is quite recent. Beevor in Allbutt's "System of Medicine" points out that progressive muscular atrophy begins either at the upper or lower end of the brachial enlargement of the cord, while the part corresponding to the sixth cervical escapes. The grouping, then, of the affected muscles, the total absence of electrical response in some of them, and the reaction of degeneration in others, together with the presence of fibrillary tremors, seem to make it certain that chronic anterior poliomyelitis exists in this case. The history and the defective development of the humerus on the left side point also to an old acute anterior poliomyelitis. But if we take this view there are three unusual features in the oase. 1. It is most exceptional for acute anterior poliomyelitis to become chronic. All the damage which is going to be done is usually done at once. And in this case there was an interval of about 12 years before the lesion became progressive. 2. Ohronic anterior poliomyelitis is not a disease of youth. Beevor states that it rarely occurs before 25 years of age, though a case has been recorded in a child, aged one and $a$ half years (Thomson and Bruce). 3. Chronic anterior poliomyelitis usually shows itself first in the small muscles of the hand. Here the shoulder girdle was attacked first, though the more ordinary procedure is being followed now, for the intrinsic muscles of the hand are degenerating faster than those affected earlier. Perhaps the previous attack of infantile palsy determined the onset of the progressive muscular atrophy in an area already damaged.

Finsbury-square, E.C.

\section{Climital aldotes:}

\section{MEDICAL, SURGICAL, OBSTETRICAL, AND THERAPEUTICAL.}

\section{A CASE OF "LATENT" PNEUMOTHORAX.}

By Richard BevaN, L.R.C.P. LOND. , M.R.C.S. ENG., D.P.H.

THE description of a case of pneumothorax recorded in a recent number of THE LANCET by Mr. E. F. Coghlan ${ }^{2}$ has prompted me to put on record the notes of a case of so. called "latent" pneumothorax which recently occurred in my practice and in which the rapidity and completeness of the patient's recovery were as remarkable as they were in the case referred to.

On Sunday, Feb. 28th, 1904, I was sent for to see a young man, aged 24 years, a clerk in an office, who until the previous Friday morning had enjoyed the most robust health. As a proof of this he assured me that although he had been in his present situation for six years he had been absent for one day only during that period on account of sickness and that was for a severe cold in the head. He gave the following history. On Thursday afternoon after finishing his day's work he wished to put away a large pile of heavy ledgers on which he had been working. In height these, when being carried, extended from his chin to the length of his outstretched arms His usual practice was to get his fingers underneath the pile, to tip them, and to allow them to fall bodily on to his chest. There was no lifting as the ledgers when resting on the desk were on a level with his chest. He had performed the same manceurre scores of times without ill effects and he at the time felt none on this particular occasion. Being anxious to have some exercise after his day's work he walked from his office home, and no pain or discomfort or difficulty in breathing made its appearance before retiring for the night, except a feeling of extreme coldness. On waking in the morning and endeavouring to get up he experienced much difficulty in breathing, the sensation being, he said, as if one lung was solid and useless. The dyspnoea and distress were much increased later and especially on any movement, yet he determined to go to the office. During the whole day he felt very ill and thought that he had pneumonia or some acnte lung trouble. On Saturday he remained at home, any

\footnotetext{
1 The LaNCet, April 16th, 1904, p. 1052
} 